\title{
UJI EFEKTIFITAS \\ KULIT BUAH NAGA BERDAGING MERAH (HylocereusPolyrhizus) SEBAGAI BAHAN PENGGANTI PEWARNA PLAK
}

\author{
Sulur Joyo Sukendro ${ }^{1}$, Bambang Sutomo ${ }^{2}$, Sariyem ${ }^{3}$
}

\begin{abstract}
ABSTRAK
Dental plaque atau plak adalah lapisan yang melekat pada permukaan gigi dan penyebab awal penyakit gigi. Untuk melihat plak diperlukan bahan pewarna plak yaitu disclosing solution.Disclosing solution tersedia dalam kemasan besar dan mahal. Bahan alternatif pengganti pewarna plak yang dapat digunakan diantaranya buah naga merah (Hylocereuspolyrhizus). Kulit buah nagayang mengandung zatwarna alamisering kali hanya dibuang. Tujuan penelitian ini adalah untuk mengetahui efektifitas ekstrak kulit buah naga merah sebagai bahan pewarna plak.

Metode penelitian yang digunakan adalah Quasi Eksperiment. Populasi penelitian seluruh mahasiswa semester I Jurusan Keperawatan Gigi Poltekkes Kemenkes Semarang dengan jumlah sampel 84 orang dibagi 2 kelompok masingmasing 42 orang. Ekstrak kulit buah naga diperoleh dengan metode ekstraksi sederhana dibuat di Laboratorium Mikrobiologi. Analisa data yang digunakan dalam penelitian ini adalah deskriptif analitik, uji organoleptik dengan uji pembedaan pasangan dan uji statistik t-tes menggunakan program aplikasi komputer.

Hasil penelitian kandungan kulit buah naga merah (Hylocereuspolyrhizus) adalah antosianin / pewarna merah dengan kandungan 0,56 $\pm 0,43$ ppm. Hasil uji organoleptik dari sisi rasa ekstrak dapat digunakan sebagai bahan pengganti pewarna plak. Namun dari sisi warna yang dihasilkan dari ekstrak belum dapat digunakan sebagai bahan pengganti pewarna plak. Berdasarkan hasil uji statistik $t$ test diketahui pada uji perbandingan skoring Indeks plak menggunakan metode PHP dengan bantuan ekstrak dan disclosing solution bahwa Sig (2 tailed $)=0.067$. Pada uji perbandingan rasa ekstrak dan disclosing solution bahwa Sig ( 2 tailed $)=$ 0.183. Pada uji perbandingan warna yang dihasilkan ekstrak dan disclosing solution bahwa Sig ( 2 tailed $)=0.000$. Sehingga dapat disimpulkan bahwa sediaan ekstrak kulit buah naga (Hylocereuspolyrhizus) dengan metode ektraksi sederhana tidak memenuhi syarat atau tidak efektif sebagai bahan pengganti pewarna plak.
\end{abstract}

Kata kunci : Kulit buah Hylocereus polyrhizus, saliva, bakteri. 


\begin{abstract}
Dental plaque or plaque is attached to the surface layer of the teeth and cause dental disease early. To see the required dye plaque that disclosing solution.Disclosing solution available in large and expensive packaging. Alternative substitution plaque dye that can be used include red dragon fruit (Hylocereus polyrhizus).Dragon fruit skin that contain natural pigments often simply discarded. The purpose of this study was to determine the effectiveness of the red dragon fruit skin extracts as coloring materials plaque.

The method used was Quasi Experiment. The study population all students of the first semester of Nursing Department of the Ministry of Health Polytechnic Semarang teeth with a sample of 84 people divided into 2 groups of 42 people each. Dragon fruit peel extract obtained by simple extraction methods were made at Laboratory of Microbiology. Analysis of the data used in this research is descriptive analytic, organoleptic test and statistical tests distinction pair t-test using a computer application program.

The results of the research content of the red dragon fruit peel(Hylocereus polyrhizus)is anthocyanin / red dye with a content of $0.56 \pm 0.43 \mathrm{ppm}$. Results of organoleptic test of the flavor extract can be used as a substitute dye plaque. But in terms of the color produced from the extract can not be used as a substitute dye plaque. Based on the statistical test $t$-test known at scoring comparative test plaque index using PHP with the help of extracts and disclosing solution that Sig (2-tailed) $=0.067$. In comparison taste test extracts and disclosing solution that Sig $(2$-tailed $)=0183$. In the comparative test the resulting extract color and disclosing solution that $\mathrm{Sig}$ (2-tailed) $=0.000$. It can be concluded that the preparation of dragon fruit peel extract(Hylocereus polyrhizus)by simple extraction methods do not qualify or are not effective as a substitute dye plaque.
\end{abstract}

Keywords: Rind Hylocereus polyrhizus, saliva, bacteria

$\overline{1,2,3}$ :Dosen Jurusan Keperawatan Gigi Politeknik Kesehatan Kemenkes Semarang 


\section{PENDAHULUAN}

Kesadarankesehatangigidanmulut

di negara - negaraberkembangtermasuk Indonesia

sangatrendah.Kesehatangigidanmulutpadasaat inibelumbegitudiperhatikankarenasebagianbes arkalanganmasyarakatbelummenyadaripentin gnyakesehatanronggamulut. Hal ini didukung data laporan Riskesdas (Kemenkes RI, 2013) bahwa prevalensinasionalmasalahgigidanmulutadala $\mathrm{h}$ 25,9 $\%$, dankemampuanuntukmendapatkanpelayanand aritenagamedisgigisebesar $8,1 \%$ Sedangkanprevalensinasionalindekskeparahan kerusakangigi (DMF-T) adalah 4,6.Hal inidisebabkankarenabanyakindividu yang menganggapbahwakesehatanronggamulutkura ngpentingdibandingkanmasalahkesehatantubu hlainnya yang sangatdiperhatikan (Ircham, 2008).

Masalah dalam rongga mulut khususnya gigi diawali dengan adanya dental plaque atau plak. Plakadalahlapisan yangmelekatpadapermukaangigidanterdapatk uman-kuman berasal dariludahdanmulut.Plakinitidaktampakbiladili hatsebab jernih dan amat tipis.Plaktidakdapatdilihatlangsungolehmatase hinggadiperlukanbahanpewarnaplak yang biasadigunakanyaitudisclosing solution(Yuwono, 1991).

$$
\text { Disclosing agentataudisclosing }
$$
solutionmerupakanalatbantu yang digunakanuntukmemperlihatkanadanyaplakpa da permukaan gigi.Disclosing solutiondapatmemberi warnaterhadapplaksecaraselektif namun tidakmempengaruhidaerahgigidansekitargigi;t idakmenimbulkanbahayabilatertelandantidak menimbulkanreaksialergi (Putri, dkk, 2011). Saat ini disclosing agent hanya dapat diperoleh di tempat tertentu dalam kemasan besar, sehingga perlu bahan alternatif pengganti yang mudah didapat.

$$
\text { Buahnaga (Dragon }
$$

Fruit)

merupakanbuahpendatang yang banyakdigemariolehmasyarakatkarenamemili kikhasiatdanmanfaatsertanilaigizicukuptinggi. Jenisbuahnaga yang telahdibudidayakan di Indonesia adaempat, antara lain Buah Naga DagingPutih (Hylocereusundatus), Buah NagaDagingMerah

(Hylocereuspolyrhizus),Buah Naga Daging Super Merah (Hylocereuscostaricensis), danBuah Naga KulitKuningDagingPutih (Selenicereusmegalanthus).Bagiandaribuahna ga $30-35 \%$ merupakankulitbuahnamunseringkalihanyadib uangsebagaisampah (Handayani dan Rahmawati, 2012).

Kulitbuahnagahanyadianggapsebagailimb ahhasilpertanian yang selamainibelumdimanfaatkansecarabaik.Pada halkulitbuahnagamengandungzatwarnaalami $a$ ntosianincukuptinggi.Antosianinmerupakanza twarna yang berperanmemberikanwarnamerahberpotensim 
enjadipewarnaalamiuntukpangandandapatdija dikanalternatif penggantipewarnasintetis yang lebihamanbagikesehatan (Handayani dan Rahmawati, 2012).

Berdasarkan uraian tersebut maka perlu dilakukan penelitian berkaitan dengan kulitbuahnagasebagaibahanpewarnaplak.Pada penelitianiniakandilakukanujiefektivitaskulitb uahnagamerah

(Hylocereuspolyrhizus)sebagaibahanalternatif pewarnaplak.

Plakberasaldari kata

plaque.Plakadalah lender yang melekat pada permukaangigi dan terdapatkumankumandariludah dan mulut.Plakinitidaktampakbiladilihatsebabber warnasepertikacaputihamat tipis (Yuwono, 1991).Plakgigisebagianbesarterdiriatas air dan berbagaimacammikroorganisme yang berkembangbiakdalamsuatumatriksinterselule r yang terdiriataspolisakaridaekstraseluler dan protein saliva. Sekitar $80 \quad \%$ dariberatplakadalah air, sementarajumlahmikroorganismekuranglebih 250 juta $\quad$ per beratbasah.Selainterdiriatasmikroorganisme, juga terdapatsel-selepitellepas, leukosit, partikel-partikelsisamakanan, garam anorganik yang terutamaterdiriataskalsium, fosfat dan fluorYuwono (1991).

SifatbahanuntukmelihatPlakmenurutYuwono (1991) : a. Dapatmemberiwarnaterhadapplaksecarase lektifsehinggatidakmempengaruhidaerahg igi dan daerahsekitargigi yang bersih

b. Tidakmengubahwarnadaristrukturmulut yang lain - pipi, bibir dan lidah

c. Tambalangigidepanjangansampaiberubah warna

d. Tidakbolehmempengaruhi rasa

e. Tidakmemberiefek yang berbahaya pada mukosamembran, juga tidakbolehmenimbulkanbahayabilatertelan dan tidakbolehmenimbulkanreaksialergi.

Cara melihat plakmenurutYuwono (1991) adalah sebagai berikut :

a. Berupalarutan :Ambillarutandisclosing solutiondengan pipet, kemudiantetes ${ }_{3}^{1 \times n}$ di ataslidah dan ratakan pada seluruhpermukaangigi.

b. Berupatablet :Kunyah tablet sampaihancur, kemudianratakankeseluruhpermukaangigi. c. Dicampurdengan pasta gigi Menurut Putri, dkk (2011), faktor-faktor yang mempengaruhi proses pembentukanplakgigiadalahsebagaiberikut :

a. Lingkunganfisik

Meliputianatomi dan posisigigi, anatomijaringansekitarnya, strukturpermukaangigiyang jelasterlihatsetelahdilakukanpewarnaande nganlarutandisclosing.

b. Friksiataugesekan oleh makanan yang dikunyah 
Hanyaterjadi pada permukaangigi yang tidakterlindung.Pemeliharaankebersihanm ulutdapatmencegahpenumpukanplak pada permukaangigi.

c. Pengaruh diet

Jenismakanan yang keras dan lunakdapatmempengaruhipembentukanpla k pada permukaangigi.

Plakbanyakterbentukjikakitalebihbanyak

mengkonsumsimakananlunak, terutamamakanan yang mengandungkarbohidratsejenissukrosa, karenaakanmenghasilkandekstran dan levan yang

memegangperananpentingdalampembentu kanmatriksplak.

Cara

pemeriksaanklinisberdasarkanindeksPlak PHP (Patient Hygiene Performance), menurut Putri, dkk (2011), cara pemeriksaan klinis berdasarkan plak PHP adalah sebagai berikut:

a. Digunakan bahan pewarna gigi yang berwarna merah (larutan disclosing)untuk memeriksa plak yang terbentuk pada permukaan gigi.

b. Pemeriksaan dilakukan pada mahkota gigi bagian facial atau lingual dengan membagi tiap permukaan mahkota gigi menjadi 5 subdivisi (Gambar 1), yaitu:

D : distal

$\mathrm{G}: 1 / 3$ tengah gingival

M : mesial

C : : 1/3 tengah

$\mathrm{I} / \mathrm{O} \quad: 1 / 3$ tengah insisal/oklusal
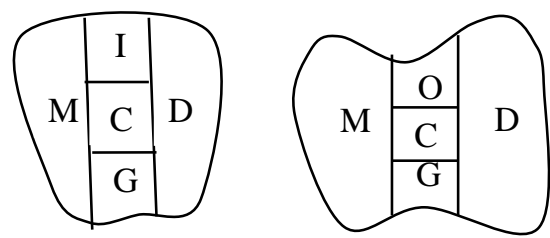

Gambar 1 Lima subdivisi permukaan gigi dalam Indeks PlakPHP

c. Cara penilaianplakadalahsebagaiberikut:

$$
\begin{aligned}
& =\text { tidakadaplak } \\
& =\text { terdapatplak }
\end{aligned}
$$

d. Cara

pengukuranuntukmenentukanindeksplak PHP yaitudenganrumus :

$$
\text { IP PHP }=\frac{\begin{array}{l}
\text { Jumlahskorplakseluruh } \\
\text { permukaan gigi yang diperiksa }
\end{array}}{\text { Jumlahgigi yang diperiksa }}
$$
Nilai yang dihasilkanberupaangka.

e. Kriteriapenilaiantingkatkeberhasilanmulut berdasarkanindeksplak PHP (Personal Hygiene Performance), yaitu :Jangkauannilaidinilaidarinilai 0 (terbaik), sampainilai 60 (Jelek), jadisemakinrendahnilainyasemakinmenun jukkanpeningkatankebersihanmulut.

Buahnagatermasukdalamkelompoktana mankaktusataufamilicuctaceaedansubfamili Hylocerenea.Dalamsubfamiliiniterdapatbeber apa genus, sedangkanbuahnagatermasukdalam genus Hylocereus. Genus inipun terdiridarisekitar 16 spesies, salah satunyaadalahHylocereuspolyrhizus (buahnagaberdagingmerah). 


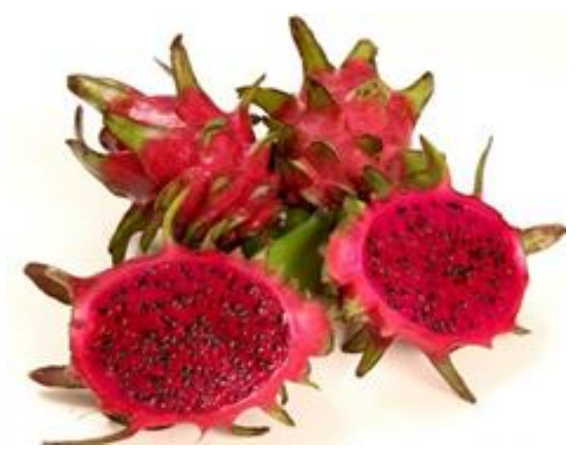

Gambar 2 Buah Naga Berdaging Merah

KlasifikasiHylocereuspolyrhizus :

Divisi : Spermatophyta

(tumbuhanberbiji)

Subdivisi : Angiospermae

(berbijitertutup)

Kelas : Dicotyledonae

(berkepingdua)

Ordo : Cactales

Family: Cactaceae

Subfamily : Hylocereanea

Genus : Hylocereus

Spesies : Hylocereuspolyrhizus

Sumber : Kristanto (2007).

Bagiandaribuahnaga

$30-35 \%$

merupakankulitbuahnamunseringkalihanyadib uangsebagaisampah.Kulitbuahnagasangatber manfaatbagikesehatannamun

pada kenyataannyahanyadianggapsebagailimbahha silpertanian yang selamainibelumdimanfaatkansecarabaik.Kulit buahnagaberdagingmerah

(Hylocereuspolyrhizus) mengandungnutrisi yang bermanfaat. Zat yang terkandungdalamkulitbuahnagaberdagingmera hyaituantosianin, antioksidan, phenol, flavonoid, protein, lemak, air, karbohidrat, abu,pentacyclictriyepenetaraxast 20ene 3aol dan

taraxast

12,20(30)dien

$3 a o l$

Kandunganzatantosianindalamkulitbuahnaga berdagingmerahcukuptinggi.Antosianinmerup akanzatwarna yang berperanmemberikanwarnamerahberpotensim enjadipewarnaalamiuntukpangan dan dapatdijadikanalternatifpenggantipewarnasint etis yang lebihamanbagikesehatan (Handayani dan Rahmawati, 2012).

Ekstrak adalah zat yang dihasilkan dari ekstraksi bahan mentah secara kimiawi. Senyawa kimia yang diekstrak meliputi senyawa aromatik, minyak atsiri, ester, dan sebagainya yang kemudian menjadi bahan baku proses industri atau digunakan secara langsung oleh masyarakat. Metode ekstraksi yang umum dilakukan yaitu:

a. Distilasi,yaituekstraksiberdasarkanbedatiti kdidihantaraekstrakdengansenyawalainny a.

b. Pemisahan berdasarkanbedamassajenisbah an yang tidakdapatbercampur.

c. Penyaringan, yaituekstraksiberdasarkanbed ajenis dan/atauukuranpartikel.

d. Absorpsi,yaitupenyerapansenyawaekstrak daribahanbakudenganbahan yang memilikiketerikatanataukelarutantinggide ngansenyawaekstrak, misalmenggunakan alcohol.

e. Termal,yaitupengambilansenyawaekstrak daribahanbakudenganmenggunakanperuba hantemperatur, sepertiekstraksisecara fluida super kritis. 


\section{f. Penumbukan,}

yaitumenghancurkanbahanhinggamenjadi

ukuran yang sangatkecil (Wikipedia, 2014).

Pembentukan plak tidak terjadi secara acak tetapi terjadi secara teratur. Partikel yang berasal dari saliva atau cairan gingiva akan terbentuk terlebih dahulu pada gigi. Pelikel merupakan lapisan yang tipis, bening dan terdiri terutama dari glikoprotein. Segera setelah pembentukan lapisan yang tipis, bakteri tipe kokus (terutama streptococcus) akan melekat ke permukaan lapisan yang tipis, yang lengket, misalnya permukaan yang memungkinkan terjadinya perlekatan dari koloni bakteri. Organisme ini akan membelah dan membentuk koloni. Perlekatan mikroorganisme akan bertambah erat dengan adanya produksi dektran dari bakteri sebagai produk sampingan dari aktivitas metabolisme. Baru kemudian, tipe organisme yang lain akan melekat pada massa dan flora gabungan yang padat, sekarang mengandung bentuk organisme filamen. Plak dapat melekat pada gigi secara supragingiva atau subgingiva, pada servik gingival atau pada poket periodontal. Kedua tipe plak tersebut dapat bevariasi karena menyerap subtansi yang berbeda dari ludah dan diet pada plak supragingiva, dan eksudat gingival, pada daerah subgingiva (Yuwono, 1991).

Lapisan plak yang menempel pada yang menempel pada permukaan gigi mempunyai warna yang sama dengan warna gigi, sehingga kurang terlihat jelas pada saat dilakukan pemeriksaan klinis. Zat yang digunakan untuk melihat biasanya mempunyai warna kontras dengan warna gigi. Dengan menggunakan disklosing atau zat pewarna dapat dengan mudah memberitahu atau mengarahkan pasien akan adanya plak dan dapat menunjukkan bersih tidaknya hasil penyikatan gigi yang telah dilakukannya (Putri, dkk, 2011).

$$
\text { Buahnaga (Dragon Fruit) }
$$

merupakanbuahpendatang yang

banyakdigemari oleh

masyarakatkarenamemilikikhasiat dan manfaatsertanilaigizicukuptinggi.Bagiandarib $\begin{array}{lll}\text { uahnaga } & 30-35 & \%\end{array}$ merupakankulitbuahnagamengandungzatwarn aalamiantosianincukuptinggi yang berperanmemberikanwarnamerahdan berpotensimenjadipewarnaalamiuntukpangan dan amanbagikesehatan (Valentina,dkk, 2010). Cara yang digunakanuntukdapatmelihatplak pada gigiadalahdenganmenggunakanzatwarna.

Pada penelitianini,

caramendapatkanpewarnaini,

didapatkandaripewarnaalami yang terdapatdalamkulitbuahnagaberdagingmerah (HylocereusPolyrhizus), yang diharapkandapatmempengaruhiwarnaplak pada gigisehinggaterlihat (Saneto, 2009).

\section{METODE PENELITIAN}


Jenis penelitianiniadalahpenelitian analitik dengan desain Quasi Eksperiment. Rancangan penelitian yang digunakan adalahgroup pre test post test (Notoadmodjo,2010).

Lokasi dan Waktu Penelitian

a. Penelitian pembuatan ekstrak kulit buah naga merah dilakukan di laboratorium Mikrobiolgi Jurusan Keperawaan Gigi Poltekkes Kemenkes Semarang pada bulan September 2016.

b. Penelitian pengukuran plak indeks dilakukan pada mahasiswa Jurusan Keperawaatn Gigi pada bulan Oktober 2016

Populasidalam penelitian ini yang menjadi populasi adalah mahasiswa tingkat I Jurusan Keperawatan Gigi 2016 yang berjumlah 104 orang.Penentuan sampel dalam penelitian ini menggunakan rumus Slovien (Sastroasmoro, 2002) sebagai berikut :

$$
n=\frac{N}{1+N e^{2}}
$$

dimana

$n \quad$ : jumlah sampel

$\mathrm{N}$ : jumlah populasi

e : batas toleransi kesalahan (error tolerance)

Sehingga :

$n=\mathrm{N} /\left(1+\mathrm{N} \mathrm{e}^{2}\right)=104 /\left(1+104 \times 0,05^{2}\right)=$ $82,5 \rightarrow 83$.

Untuk memudahkan kelompok penelitian jumlah sampel ditentukan 84 mahasiswa dibagi 2 kelompok, yaitu 42 orang untuk kelompok eksperimen dan 42 orang untuk kelompok kontrol.

Analisa data yang digunakan dalam penelitian ini adalah deskriptif analitik yaitu dengan cara mendeskripsikan variabel ekstrak kulit buah naga sebagai bahan pewarna plak dalam bentuk tabel dan grafik.Untuk mengetahui penerimaan konsumenterhadap ekstrak kulit buah naga merah sebagai bahan pewarna plak maka digunakan uji organoleptik dalam hal ini ujipembedaan pasangan.Tujuan uji pembedaan pasangan adalah menguji atau menilai ada tidaknya perbedaan antara dua macam produk, dalam hal ini produk yang diuji adalah ekstrak kulit buah naga merah, sedangkan produk pembanding adalah disclosing solution yang telah diterima oleh masyarakat. Untuk mengetahui efektifitas ekstrak kulit buah naga dilakukan uji statistik t-tes menggunakan program aplikasi statistik di komputer.

\section{HASIL DAN PEMBAHASAN}

Pengamatan sediaan bahan yang akan digunakan

Sediaan buah naga yang digunakan adalah buah naga berkulit merah :

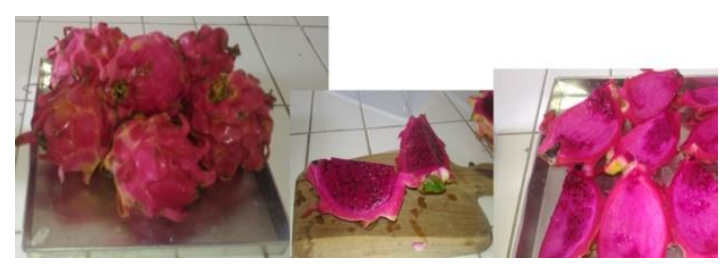

Gambar 3 Buah naga berkulit merah

Kulit buah naga merah ini yang digunakan dalam penelitian berupa sediaan ektrak kulit buah naga. 
Sediaan ekstrak kulit buah naga dan disclosing solution yang akan digunakan dalam penelitian ini adalah sebagai berikut:

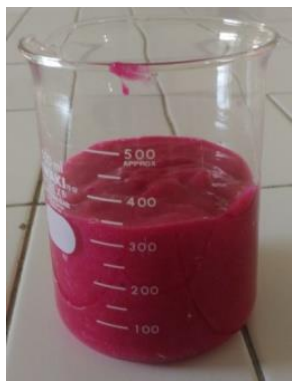

(a)

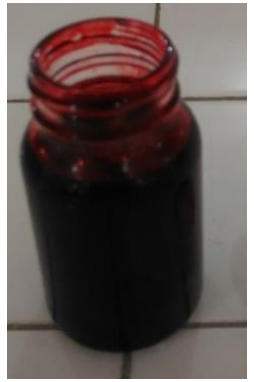

(b)
Gambar 4(a)Sediaan ekstrak kulit buah naga ,(b)disclosing solution

Dari pengamatan foto tersebut tampak bahwa pada sediaan ektrak kulit buah naga kental seperti bubur sedangkan disclosing solution encer / cair .

Berdasarkan hasil pengamatan setelah pengolesan bahan pewarna gigi diperoleh gambaran sebagai berikut :

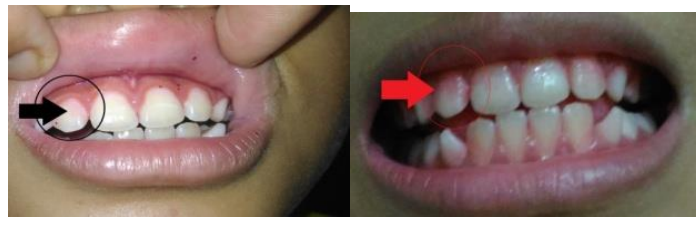

(a)

(b)

Gambar 5 (a)Hasil pengolesan ekstrak kulit buah naga dan (b)disclosing solution

Dari pengamatan foto tersebut tampak bahwa pada pengolesan ektrak kulit buah naga kurang memberikan warna merah pada plak di permukaan gigi dibandingkan kontrol (disclosing solution).

Skor Indeks plak setelah perlakuan dapat dilihat pada grafik sebagai berikut :

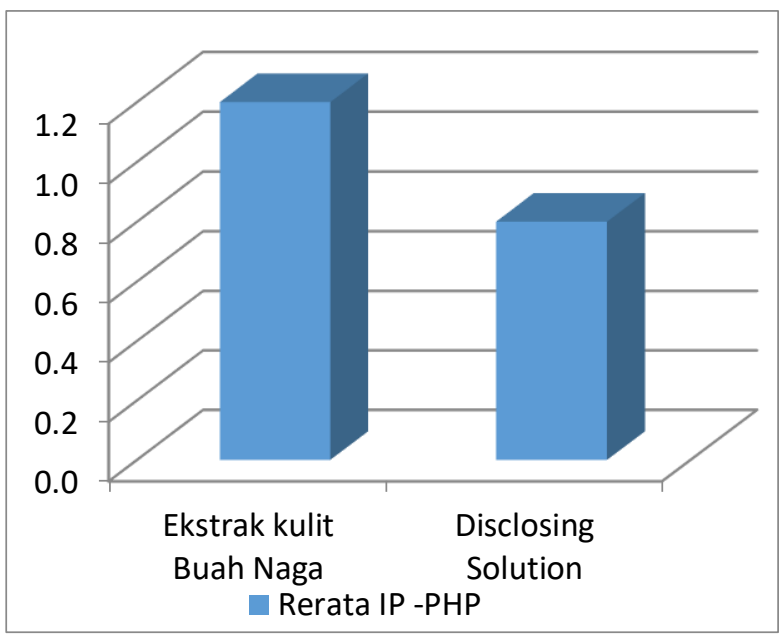

Gambar 6. Grafik rerata Indeks Plaks menggunakan pengukuran PHP

Berdasarkan grafik 6 tampak bahwa kedua perlakuan dapat digunakan untuk membantu memudahkan pengukuran Indeks Plak menggunakan metode PHP, meskipun pada kelompok dengan pengolesan ekstrak kulit buah naga skornya lebih tinggi dibandingkan pada kontrol.

Hasil uji organoleptik dengan metode uji pembedaan pasangan dari produk ekstrak kulit buah naga pada 42 responden dapat dilihat pada tabel berikut :

Tabel 1 Hasil uji organoleptik

\begin{tabular}{|c|c|c|c|c|}
\hline \multirow{2}{*}{ Uraian } & \multicolumn{2}{|c|}{$\begin{array}{c}\text { Ekstrak Kulit } \\
\text { Buah Naga }\end{array}$} & \multicolumn{2}{c|}{$\begin{array}{c}\text { Kontrol } \\
\text { (Disclosing } \\
\text { Solution) }\end{array}$} \\
\cline { 2 - 5 } & Rasa & Warna & Rasa & Warna \\
\hline Penilaian & 21 & 26 & 15 & 42 \\
\hline$\%$ & $50 \%$ & $62 \%$ & $36 \%$ & $100 \%$ \\
\hline
\end{tabular}

Dari sisi rasa berdasarkan hasil uji tampak bahwa pada perlakuan dengan ekstrak kulit buah naga dari 42 responden, 21 orang responden $(50 \%)$ menyatakan sediaan memiliki rasa manis atau rasa buah, 
sedangkan pada kontrol hanya 15 orang responden $(30 \%)$ yang menyatakan sediaan memiliki rasa manis.

Dari sisi warna berdasarkan hasil uji tampak bahwa pada perlakuan dengan ekstrak kulit buah naga dari 42 responden, 26 orang responden (62\%) menyatakan plak dapat terlihat setelah dioleskan dan berkumur ringan, sedangkan pada kontrol seluruh responden $(100 \%)$ yang menyatakan sediaan dapat digunakan untuk melihat plak.

Hasil uji statistik menggunakan uji paired t-tes setelah perlakuan dapat dilihat pada tabel sebagai berikut :

Tabel 2 Paired Sample Test

\begin{tabular}{|ll|r|}
\hline & \multicolumn{1}{c|}{$\begin{array}{c}\text { Sig. } \\
\text { (2-tailed) }\end{array}$} \\
\hline Pair 1 & IP_X1 - IP_X2 & .067 \\
Pair 2 & Rasa_X1 - Rasa_X2 & .183 \\
Pair 3 & Warna_X1 - Warna_X2 & .000 \\
\hline
\end{tabular}

Dari output uji berpasangan ke-1 yaitu perbandingan skoring Indeks plak menggunakan metode PHP dengan bantuan ekstrak kulit buah naga dan disclosing solutiondapat dilihat bahwa Sig (2 tailed $)=$ 0.067. Hal itu berarti bahwa probabilitas lebih dari 0.05 yang berarti tidak ada perbedaan hasil Indeks Plak dengan cara PHP antara perlakuan ekstrak kulit buah naga dan disclosing solution.

Dari output uji berpasangan ke-2 yaitu perbandingan rasa ekstrak kulit buah naga dan disclosing solutiondapat dilihat bahwa Sig $(2$ tailed $)=0.183$. Hal itu berarti bahwa probabilitas lebih dari 0.05 yang berarti tidak ada perbedaan rasa antara perlakuan ekstrak kulit buah naga dan disclosing solution.

Dari output uji berpasangan ke-3 yaitu perbandingan warna yang dihasilkan ekstrak kulit buah naga dan disclosing solution dapat dilihat bahwa Sig (2 tailed $)=0.000$ pada uji warna pada perlakuan ekstrak kulit buah naga dan disclosing solution. Hal itu berarti bahwa probabilitas kurang dari 0.05 yang berarti ada perbedaan warna yang dihasilkan antara perlakuan ekstrak kulit buah naga dan disclosing solution.

Berdasarkan Gambar 5dari pengamatan foto tersebut tampak bahwa pada pengolesan ektrak kulit buah naga kurang memberikan warna merah pada plak di permukaan gigi dibandingkan kontrol (disclosing solution), hal kemungkinan disebabkan antosianin terikat menjadi satu oleh getah yang berasal dari kulit buah naga. Pada penelitian ini antosianin belum diuraikan dari getah kulit buah naga dengan pertimbangan kemudahan metode bila bahan akan digunakan oleh masyarakat.

Meskipun pengolesan ektrak kulit buah naga kurang memberikan warna merah pada plak di permukaan gigi namun masih dapat membantu memudahkan pengukuran Indeks Plak menggunakan metode PHP. Hal ini dibuktikan pada gambar 5 pada kelompok dengan pengolesan ekstrak kulit buah naga skornya juga dapat dihitung dibandingkan pada kontrol. Dan juga didukung tabel 2 hasil 
uji statistik t-test uji berpasangan ke-1 yaitu perbandingan skoring Indeks plak menggunakan metode PHP dengan bantuan ekstrak kulit buah naga dan disclosing solutiondapat dilihat bahwa Sig $(2$ tailed $)=$ 0.067. Hal itu berarti bahwa probabilitas lebih dari 0.05 yang berarti tidak ada perbedaan hasil Indeks Plak dengan cara PHP antara perlakuan ekstrak kulit buah naga dan disclosing solution.

Hasil uji organoleptik dengan metode uji pembedaan pasangan dari produk ekstrak kulit buah naga pada 42 responden dapat dilihat dari sisi rasa berdasarkan hasil uji tampak bahwa pada perlakuan dengan ekstrak kulit buah naga dari 42 responden, 21 orang responden $(50 \%)$ menyatakan sediaan memiliki rasa manis atau rasa buah, sedangkan pada kontrol hanya 15 orang responden $(30 \%)$ yang menyatakan sediaan memiliki rasa manis. Hal ini membuktikan bahwa ekstrak kulit buah naga memiliki rasa yang tidak mengganggu responden bila digunakan sebagai bahan pengganti pewarna plak. Dan juga didukung tabel 2 hasil uji statistik t-test uji berpasangan ke-2 yaitu perbandingan rasa ekstrak kulit buah naga dan disclosing solutiondapat dilihat bahwa Sig (2 tailed) $=0.183$. Hal itu berarti bahwa probabilitas lebih dari 0.05 yang berarti tidak ada perbedaan rasa antara perlakuan ekstrak kulit buah naga dan disclosing solution.

Sedangkan dari sisi warna berdasarkan hasil uji organoleptik metode uji pembedaan pasangan, tampak bahwa pada perlakuan dengan ekstrak kulit buah naga dari 42 responden, 26 orang responden (62\%) menyatakan plak dapat terlihat setelah dioleskan dan berkumur ringan, sedangkan pada kontrol seluruh responden $(100 \%)$ yang menyatakan sediaan dapat digunakan untuk melihat plak. Kondisi ini belum mencapai derajat kemaknaan yang diharapkan 95\%. Hal ini membuktikan bahwa ekstrak kulit buah naga belum dapat digunakan sebagai bahan pengganti pewarna plak. Dan juga didukung tabel 2 hasil uji statistik t-test uji berpasangan ke-3 yaitu perbandingan warna yang dihasilkan ekstrak kulit buah naga dan disclosing solution dapat dilihat bahwa Sig (2 tailed) $=0.000$, probabilitas kurang dari 0.05 yang berarti ada perbedaan warna yang dihasilkan antara perlakuan ekstrak kulit buah naga dan disclosing solution.

\section{KESIMPULAN}

Kesimpulan yang dapat disusun berdasarkan hasil penelitian ini adalah sebagai berikut :

1. Kandungankulitbuahnaga merah

\section{(Hylocereuspolyrhizus)yang}

dapatdigunakanuntukpewarnaplak adalah antosianin. Kandungan antosianin padakulitbuahnagamerahsebesar $0,56 \pm 0,43$ ppm. Antosianinmerupakanzatwarna yang berperanmemberikanwarnamerah, sehinggasemakinmerahwarnakulitbuahna gasemakintinggikadarantosianinnya. 
2. Berdasarkan hasil uji organoleptik, dari sisi

rasa

kulitbuahnagamerah(Hylocereuspolyrhiz

us) dapat digunakan sebagai bahan pengganti pewarna plak. Namun dari sisi warna yang dihasilkan dari ekstrak kulitbuahnagamerah(Hylocereuspolyrhiz $u s$ ) belum dapat digunakan sebagai bahan pengganti pewarna plak.

3. Berdasarkan beberapa hasil uji statistik $t$ test yaitu :

a. Uji berpasangan ke-1 yaitu perbandingan skoring Indeks plak menggunakan metode PHP dengan bantuan ekstrak kulit buah naga dan disclosing solutionbahwa Sig (2 tailed) $=0.067$ disimpulkan tidak ada perbedaan hasil dari kedua metode pengukuran.

b. Uji berpasangan ke-2 yaitu perbandingan rasa ekstrak kulit buah naga dan disclosing solutionbahwa Sig $(2$ tailed $)=0.183$. disimpulkan tidak ada perbedaan rasa antara kedua sediaan.

c. Uji berpasangan ke-3 yaitu perbandingan warna yang dihasilkan ekstrak kulit buah naga dan disclosing solution bahwa Sig (2 tailed) $=0.000$ disimpulkan ada perbedaan warna antara kedua sediaan.

Dapat disimpulkan bahwa sediaan ekstrak kulit buah naga
(Hylocereuspolyrhizus)dengan metode ektraksi sederhana tidak memenuhi syarat atau tidak efektif sebagai bahan pengganti pewarna plak.

\section{SARAN}

A. Perlu dilakukan penelitian lanjutan berkaitan dengan metode ektraksi untuk mendapatkan antosianin yang terkandung di kulit buah naga merah (Hylocereuspolyrhizus). Mengingat antosianin merupakan zat warna merah yang dapat digunakan sebagai bahan pengganti pewarna plak.

B. Perlu dilakukan penelitian lanjutan berkaitan dengan antosianin yang terkandung dari bagian buah naga merah (Hylocereuspolyrhizus) dan metode ektraksi antosianin yang mudah dilakukan oleh masyarakat.

\section{DAFTAR PUSTAKA}

Daniel R. S, Osfar S, Irfan H. D, 2014,Skripsi :Kajian Kandungan Zat Makanan Dan Pigmen AntosianinTiga Jenis Kulit Buah Naga (Hylocereus Sp.)Sebagai Bahan Pakan Ternak,Universitas Brawijaya Malang, Tanggal Akses 17/11/2014, 19:36 WIB

Kemenkes RI, 2009, Undang-undang Kesehatan No.36, Jakarta.

Kemenkes RI, 2013, Laporan Riset Kesehatan Dasar (RISKESDAS) 2013 , Jakarta.

Ircham, M., 2008, Menjaga Kesehatan Gigi dan Mulut Anak-anak dan IbuHamil, Fitramaya, Yogyakarta. 
Yuwono, L., 1991, Pencegahan Penyakit Mulut (Preventive Dentistry), Hipokrates, Jakarta.

Kristanto, D., 2009, Buah Naga Pembudidayaan di Pot, Panebar Swadaya, Jakarta.

Handayani, P.A., Rahmawati, A., 2012, Jurnal Bahan Alam Terbarukan : Pemanfaatan Kulit Buah Naga (Dragon Fruit) sebagai Bahan Pewarna Alami Makanan Pengganti Pewarna Sintetis, Volume 1, No. 2, 19-24.

Putri, M.H., Herijulianti, E., Nurjannah, N., 2011, Ilmu Pencegahan Penyakit Jaringan Keras dan Jaringan Pendukung Gigi, EGC, Jakarta.

Wikipedia, 2014, Ekstrak, http://id.wikipedia.org/wiki/Ekstrak, diakses tanggal 10 November 2014.
Notoadmodjo, S, 2010, Metodologi Penelitian Kesehatan, Rineka Cipta, Jakarta.

Hadioetomo, R.S., 1985, Mikrobiologi Dasar Dalam Praktek Teknik dan Prosedur Dasar Laboratorium, Gramedia, Jakarta.

Saneto, B., 2010, Karakterisasi Kulit Buah Naga Merah (H. polyrhizus), Agrika, Malang.

Valentina, N.K., Nurhandayatun, N., Mudehir, M., 2010, Jurnal Poltekkes Jambi : Efektivitas Berbagai macam Sumba Sebagai Bahan Pengganti Disclosing Solution Untuk Mendeteksi Adanya Plak di Dalam Mulut, http://issuu.com/jurnal poltekkes jambi /docs/jurnal_poltekkes_jambi_vol_6, diakses tanggal 5 November 2014.

Sastroasmoro, S., 2002, Dasar-dasar Metodologi Klinis, Sagung Seto, Jakarta. 